\title{
Profile of skin cancer in Pomeranian communities of the State of Espírito Santo
}

\section{Panorama do câncer da pele em comunidades de imigrantes Pomeranos do Estado do Espírito Santo}

Patrícia Henriques lyra Frasson'; Danilo Schinab Duque1; Estanrley Barcelos Pinto1; Giulia Cerutti Dalvi'; Sammy Zogheib Madalon ${ }^{1}$; Tarcizo Afonso Nunes33; Paulo Roberto Merçon de-Vargas².

\begin{abstract}
A B S T R A C T
Objectives: to evaluate the profile of skin cancer in Pomeranian communities of the State of Espirito Santo, composed of descendants of European immigrants, regarding gender and age at diagnosis, lesion size and histological type. Method: we studied histopathological reports of 3,781 patients operated between 2000 and 2010, with resection of 4,881 lesions. We assessed histological type, lesion size, age and gender of the patients at diagnosis and their correlations in the 11-year period. Results: the histopathological examination revealed basal cell carcinoma in 3,159 patients (83.5\%), squamous cell carcinoma in 415 (11\%), melanoma in 64 (1.7\%), and 143 patients (3.8\%) had combined lesions of basal cell carcinoma and squamous cell carcinoma. As to size, $47.1 \%$ measured between $5.1 \mathrm{and} 10 \mathrm{~mm}$. The age group of 61 to 70 years was the one that sustained the largest number of surgical interventions (24.3\%). There was a predominance of the female gender $(2,027,53.6 \%)$ in relation to the male $(1,754,46.4 \%)$. Conclusion: basal cell carcinoma was the most frequent histological type. The prevalences of squamous cell carcinoma and melanoma were below the national estimate of the National Cancer Institute. The diagnosis of tumors occurred at more advanced ages (above 60 years) and there was an increase in the incidence and size of skin tumors in the male population.
\end{abstract}

Keywords: Skin Neoplasms. Carcinoma, Basal Cell. Carcinoma, Squamous Cell. Occupational Exposure. Emigrants and Immigrants.

\section{INTRODUCTION}

$S_{a}^{k}$ in cancer is the most common malignant neoplasm among Brazilians ${ }^{1}$, making it a serious public health problem. Its incidence has been increasing in recent years and this is mainly due to sun exposure.

In 1859, the state of Espírito Santo received a significant number of Pomeranians, immigrants from the region between Germany and Poland, who fled the persecution of the tsarist regime. It is one of the largest concentrations of Pomeranians in Brazil, with the majority residing in the interior of the state, farmingbeing their main activity. Prolonged exposure to the sun associated with skin type (white, light eyes and hair) has contributed to the appearance of several skin lesions over the years.

Pomeranians live far from the capital and still have communication difficulties because not all of them speak Portuguese. Some members of this community only speak their own dialect. These characteristics contributed to the delay in the diagnosis and treatment of skin cancer, culminating with large tumors and deformities caused by neoplasia.

Realizing this fact, in 1986, the Dermatology and Plastic Surgery Services of the Federal University of Espírito Santo created the University Extension Project entitled "Dermatological Assistance Program to Pomeranian Farmers in Espírito Santo" (PAD). This project is developed in partnership with the state health secretariat, cityhalls and the Lutheran church, to guarantee treatment in loco to this population, in a campaign regime. Annual visits are carried out in the 11 municipalities with the highest number of Pomeranians, focusing on guidance, diagnosis and treatment of skin cancer. Each campaign comprises 300-500 clinical visits and 60 to 100 surgical procedures. The surgical specimens are sent to the Pathology Department of the Cassiano Antonio Moraes University Hospital (HUCAM-UFES).

1 - Federal University of Espírito Santo, Department of Specialized Medicine, Plastic Surgery Service, Vitória, Espírito Santo State, Brazil. 2 - Federal University of Espírito Santo, Department of Pathology, Vitória, Espírito Santo State, Brazil. 3 - Federal University of Minas Gerais, Department of Surgery, Surgery Service, Belo Horizonte, Minas Gerais State, Brazil. 
The objective of this research was to evaluate the profile of skin cancer in the 11 communities served by the PAD, regarding patients'histological type, tumor size, age and gender.

\section{METHODS}

This is a retrospective study on records to the patients attended by the PAD between 2000 and 2010 carried out in the archives of the HUCAM-UFES Pathology Service. The research was approvedby the Ethics in Research Committee of the Federal University of Espírito Santo, under number 093/2010.

The patients were evaluated once a year in each municipality. In the dermatological evaluation, when diagnosed with actinic keratosis, they received treatment with $5 \%$ fluorouracil or imiquimode for topical use, cryotherapy, or surgery in hypertrophic cases. Lesions suggestive of carcinoma, melanoma or atypical melanocytic lesions were referred for surgical treatment, in loco, with the plastic surgery team. Large-volume lesions or patients without adequate clinical conditions were referred for treatment in the state capital.

A surgical treatment was performed on 5,543 patients and 7,225 skin lesions were excised. Medical students supervised by two plastic surgeons performed the procedures. The surgical specimens were sent to the HUCAM Pathology Service, which generated 7,225 histopathological reports, as described in Table 1.

Table 1. Histopathological diagnosis of surgical specimens obtained by the Program of Dermatological Assistance Pomeranian Farmers (PAD) between 2000 and 2010.

\begin{tabular}{ccc}
\hline Diagnosis & $\mathrm{N}$ & $\%$ \\
\hline BCC $^{*}$ & 4,195 & 58.1 \\
SCC** & 606 & 8.4 \\
Melanoma & 80 & 1.1 \\
Premalignant lesions*** & 1,367 & 18.9 \\
Other malignant neoplasms & 14 & 0.2 \\
Other benign tumors & 963 & 13.3 \\
Total & 7,225 & 100 \\
\hline
\end{tabular}

* BCC: Basal Cell Carcinoma; ** SCC: Squamous Cell Carcinoma; Premalignant lesions: actinic keratosis and atypical melanocytic nevi.
We studied 4,881 reports of 3,781 patients, of which 1,754 were male (46.4\%) and 2,027 female (53.6\%). The majority, 3,296 patients (87.2\%), were farmers. The age ranged from ten to 99 years, $52.7 \%$ being over 60 , with a median of 62 . The number of surgical procedures varied from one $(78.8 \%)$ to seven $(0.03 \%)$ per individual, totalizing the resection of 4,881 lesions. We categorized the size of the lesion in its largest diameter with intervals of $5 \mathrm{~mm}$ and evaluated it considering only one lesion per individual, according to the mean, median, standard deviation and linear regression.

We categorized age at 10-year intervals and assessed it according to mean, median, standard deviation and linear regression, and gender, by means of simple frequency analysis.

We carried out the data analysis data by individual, considering only one lesion, with random exclusion of the other lesions. From the data obtained, were made correlations between the variables (age, histological diagnosis, tumor size and gender), as described below.

We entered and analyzed the data in an Excel spreadsheet (Microsoft@) and SPSS 19.0 program

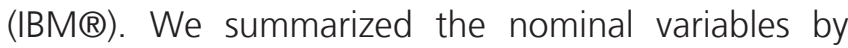
simple frequency and the dimensional ones by the mean, median and standard deviation. We used concordance analyzes and linear regression, and the level of significance was $\alpha=0.05$. We considered a significant trend the one whose estimated regression model obtained $p<0.05$.

\section{RESULTS}

Histopathological examination revealed basal cell carcinoma (BCC) with variations in 3,159 patients (83.5\%), squamous cell carcinoma (SCC) in 415 (11\%), melanoma in $64(1.7 \%)$ and combined BCC and SCC in 143 patients (3.8\%).

In the analysis by number of lesions, the histopathological examination presented 4,195 BCC (85.9\%), 606 SCC (12.4\%) and 80 melanomas (1.7\%). When evaluating the BCC/SCC ratio by the linear regression model, there was no tendency towards increase in this proportion $(p=0.233)$, but we noticed a 
Table 2. Size of tumors categorized according to the number of individuals.

\begin{tabular}{ccc}
\hline Size of the lesion & $\mathrm{N}$ & $\%$ \\
\hline 0 to $5 \mathrm{~mm}$ & 793 & 21 \\
5.1 to $10 \mathrm{~mm}$ & 1,782 & 47.1 \\
10.1 the $15 \mathrm{~mm}$ & 765 & 20.2 \\
15.1 to $20 \mathrm{~mm}$ & 254 & 6.7 \\
Above $20 \mathrm{~mm}$ & 171 & 4.5 \\
Without information & 16 & 0.4 \\
Total & 3,781 & 100 \\
\hline
\end{tabular}

disproportion of the number of BCC in relation to the number of SCCS, whose mean was 7.32.

Skin tumors showed the following measurements: BCC ranged from $1 \mathrm{~mm}$ to $78 \mathrm{~mm}$, median of eight; SCC, from 2.2 to $45 \mathrm{~mm}$, and melanoma, from $2 \mathrm{~mm}$ to $46 \mathrm{~mm}$, both with a median of $10 \mathrm{~mm}$. During the evaluated period, there was a tendency to increase in the mean tumors size evidenced by the linear regression $(p=0.047)$. After categorization, we observed that $47.1 \%$ of the tumors measured between 5.1 and $10 \mathrm{~mm}$, the other measures showing lower percentages (Table 2).

Considering all patients, the mean age at diagnosis was 60.7 years. The age group of 61 to 70 years was the one that sustained the largest number of surgical interventions, $23.7 \%$. Considering the histological diagnosis, the mean patients' age was 50.27 years for melanoma, 60.53 years for BCC and 62.4 years for SCC (Table 3 ).

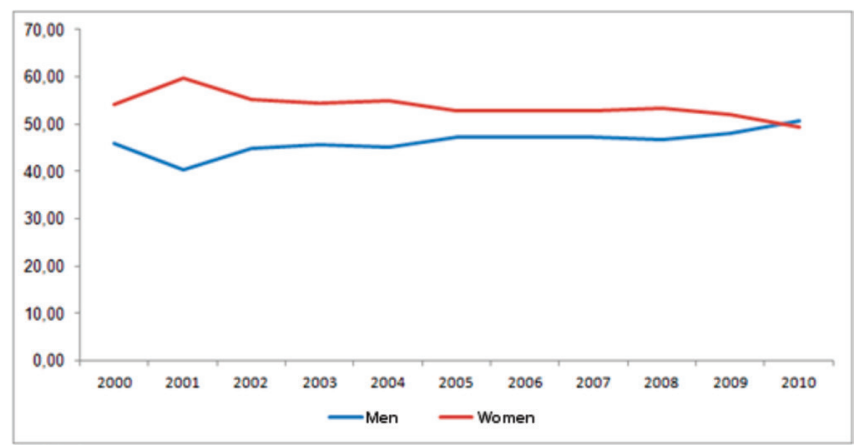

Figure 1. Number of surgical procedures performed on men and women over the course of 11 years.

Through the correlation between age and diagnosis by the Kruskal-Wallis test, there was a significant difference in the histopathological diagnosis. Using the Dunn Test, we found that all diagnoses differed from each other and the highest ages were in patients with combined lesions (concomitant BCC and SCC), followed by SCC, BCC, and melanoma. There was no significant difference between genders.

There was a predominance of the female gender $(2,027,53.6 \%)$ over the male $(1,754,46.4 \%)$, but without significance. The linear regression analysis, however, revealed a growing tendency of skin cancer diagnosedin men and decreasing in women, with a consequent increase in the male/female ratio over the years (Figure 1).

When comparing the tumor largest diameter with the patients' age groups and using the Spearman's correlation coefficient, we observed that there was a significant, though weak, correlation between age and lesion size, whose coefficient was 0.096. That is, as age increases, the size of the lesion also increases (Figure 2).

Table 3. Age according to patients' histologic diagnosis and gender.

\begin{tabular}{lcccccccccc}
\hline & & \multicolumn{4}{c}{ Age } & & \multicolumn{3}{c}{ Test results */** and Dunn test } \\
\cline { 2 - 10 } & Variables & $N$ & Min & Max & Median & Average & $\begin{array}{c}\text { Standard } \\
\text { deviation }\end{array}$ & $\begin{array}{c}p \\
\text { value }\end{array}$ & $\begin{array}{c}\text { average } \\
\text { posts }\end{array}$ & $\begin{array}{c}\text { Statistically significant difference } \\
(p<0.05)\end{array}$ \\
\hline \multirow{3}{*}{ * Histopathological } & SCC & 3,158 & 16 & 99 & 61 & 60.53 & 14.73 & & $1,870.26$ & SCC, Melanoma and combined \\
Diagnosis & 415 & 14 & 95 & 62 & 62.4 & 14.53 & 0.000 & $2,008.48$ & BCC, Melanoma and combined \\
& Melanoma & 64 & 10 & 88 & 47 & 50.27 & 20.76 & & $1,324.14$ & BCC, SCC and combined \\
& Combined & 143 & 33 & 88 & 68 & 65.56 & 11.99 & $2,248.56$ & BCC, SCC and melanoma \\
\hline \multirow{2}{*}{$*$ Gender } & Male & 1,754 & 12 & 98 & 62 & 60.85 & 14.15 & 0.986 & $1,890.16$ & \\
& Female & 2,027 & 10 & 99 & 62 & 60.66 & 15.41 & & $1,890.80$ & \\
\hline
\end{tabular}

* Kruskal-Wallis test; $n=$ number of patients; $B C C=$ basal cell carcinoma; Combined $=B C C+S C C$.

**Mann-Whitney Test; age expressed in years; SCC= squamous cell carcinoma. 


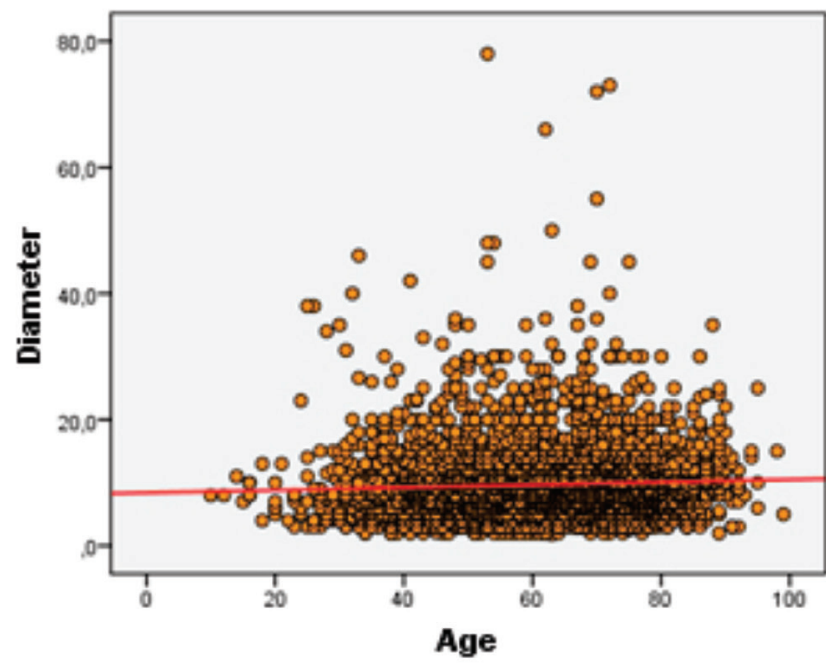

Figure 2. Correlation between age and tumor size.

As for histological diagnosis, only the BCC differed from all others, being the one that had the smallest lesions. Patients diagnosed with SCC, melanoma, and combined lesions had lesions of similar size. Males (median $9 \mathrm{~mm}$ ) had higher lesion size values than females (median $8 \mathrm{~mm}$ ). There was a significant difference between lesion size, histopathological diagnosis and gender.

\section{DISCUSSION}

The histopathological diagnosis in the analyzed population differs from the world and the country statistics, with $85.94 \%$ BCC and $12.41 \%$ SCC, a BCC/SCC ratio ranging from 4.33 to 11.71 , with a mean of 7.32:1. This is well above the numbers in the literature, from 3:1 and $1.64 \%$ melanoma, similar to the study by Ferreira and Nascimento ${ }^{2}$, but much lower than described in the literature $\mathrm{e}^{2,3}$.

Actinic keratosis is recognized as a potential SCC precursor. However, true transformation rates are difficult to measure and estimates range from $<0.1 \%$ to $0.6 \%$ per year until malignant transformation of $20 \%$ to $25 \%$ of the lesions ${ }^{4,5}$. Although it is not possible to predict which keratoses could progress to SCC, it is accepted that the presence of keratosis is a risk marker for the patient and therefore should be treated to avoid possible morbidity and mortality ${ }^{4,6}$. Thus, early intervention recommended in this program for this condition, could explain the decrease in the diagnosis rate of squamous cell carcinoma and the increase in the BCC/SCC ratio.

At the Global Skin Cancer Conference, in 2011, was reported that most of the economic burden of melanoma is a result of the treatment of nevi, especially in young patients. In agreement with this research ${ }^{4}$, this study credits the low rate of diagnosis of melanoma to the early resections of suspicious melanocytic lesions.

In the literature, the diameter of skin cancer lesions ranged from $1.7 \mathrm{~mm}$ to $3.9 \mathrm{~mm}^{3,6,7}$. In this work, even with the educational actions for the population, the diameter varied between $1 \mathrm{~mm}$ and $78 \mathrm{~mm}$. This result is much higher than expected and with a significant increasingtendency, as verified by the linear regression analysis ( $p=0.047)$, with a mean annual increase percentage of $0.002 \%$. The BCC were the smallest, with a median of $8 \mathrm{~mm}$, SCC and melanomas with median of $10 \mathrm{~mm}$, and the combined lesions with $9.3 \mathrm{~mm}$.

By analyzing the lesionslarger diameter and comparing it with the age groups, we verified a significant association, that is, the lesion diameter at diagnosis tends to be higher in groups of more advanced ages. Lesions in males were larger in diameter than those in females were.

Although the size found was greater than expected, the median of all lesions was below $2 \mathrm{~cm}$ in their largest diameter, that is, the TNM categories of skin tumors remained below T1 $(\leq 2 \mathrm{~cm})$.

The analysis of the mean ages of patients with different clinical types of cutaneous cancer revealed data similar to those in the literature ${ }^{3,8-12}$, whose mean remained over 60 years. The age group of 61 to 70 years was the one that sustained the largest number of surgical interventions (24.3\%). Regarding the three types of tumors, the patients mean age was 50.27 years for melanoma (similar to the data from the Brazilian Melanoma Group), 60.53 years for BCC (a result similar to that found in the studies developed by Bariani et al. ${ }^{10}$ and Silveira et al. ${ }^{13}$ ) and 62.4 for SCC.

When comparing the patients mean age during the study 11 -year period, there is a trend towards the diagnosis of skin tumors at more advanced ages and the main histological types found were combined lesions (BCC associated with SCC), followed by SCC. 
The incidence of carcinoma was higher in women (53.7\%), but without significance in comparison to men, which is similar to studies by Ferreira and Nascimento ${ }^{2}$ and Machado Filho et $a l .{ }^{9}$, but in disagreement with other publications ${ }^{14-16}$. However, linear regression analysis showed a tendency to increase in the number of diagnoses in men and decreasing in women. When analyzing the care curve (Figure 1), we concluded that, after 11 years, the trend is that diagnoses of skin cancer in men exceed the number of women, as observed in the literature.

We believed that, over the years, continuous action on the same communities would lead to a reduction in the size of the lesions and in the age at diagnosis would tend to fall. This forced us to review the data and carry out a joint analysis of the obtained results.

Culturally and for aesthetic reasons, women tend to seek medical services more often than men, which enables diagnosis and treatment in early stages of disease. The progressive increase in surgeries in men, however, suggests that working with this community provided access to all family members, including the male population. This fact may explain the change in the expected results curve, since the diagnosis in men occurred at a higher age than in the women, and the delay in the search for care would explain the larger diameter of such lesions. Thus, the larger size of the lesions may be translated into a repressed demand of men, presenting with lesions greater than the womendo at diagnosis.

The increase in the number of skin cancer diagnoses is expected, since the aggression imposed on the environment has caused the reduction of the ozone layer and protection against ultraviolet radiation. Another contributing factor is exposure to the sun during work or the worship of body tanning.

Patients with current age of 55 years received the first guidelines when they were about 30 years old, and had the opportunity to prevent or start treatment. The diagnosis in older patients reflects the use of adequate protection during youth, be it chemical or of barrier, as well as the early resection of pre-malignant lesions.

Although visits are given only once a year in each municipality, the program is important because the patient has access to the dermatologist and the plastic surgeon at the same time, without the need to go to the capital or to regional centers. The presence of community members who participate as volunteers or as health agents contributes to the credibility of the program in the community.

The results of this research show the profile of skin cancer in the population of these 11 municipalities and consolidate the importance of specific treatment to these populations and to others with similar characteristics. Investing in early prevention and treatment programs may reduce the prevalence of SCC and melanoma, keeping the age of diagnosis concentrated at 60 years. The most relevant result of this program, however, is the patients' prevention and cure.

Skin cancer is the most prevalent tumor in the population. Therefore, health policies aimed at prevention and early treatment are necessary. The dermatological care program greatly contributes to the management of skin cancer in these communities, but it cannot be adopted as an isolated treatment policy. It should also be seen as a means of providing training to local professionals. In addition, visits by health professionals help to continually remind the importance of basic measures and ensure access to health care for a community with unique characteristics.

There must be continuous investment in education, training of health agents, encouragement to self-examination, guidelines on the emergence of suspicious lesions and establishment of a pathway for patients' referral for evaluation with a multidisciplinary team, in loco or through teleconference. The delivery of digital photodermatoscopy for evaluation in specialized regional centers with subsequent access to the surgeon is an alternative for patients residing in distant areas.

The adoption of a unique identification number of the individual, through the SUS card, will enable the creation of a more reliable database, allowing to know the actual number of patients with lesions removed, regardless of where the patient was treated, the evolution, and to plan treatment adequately.

BCC is the most frequent skin cancer in Pomeranian communities. The prevalence of SCC and melanoma is in decline. The diagnosis of tumors occurred in older patients and there was an increased incidence and size of tumors in the male population. Tumors, although showing growth, remained on average, smaller than $2 \mathrm{~cm}$. 


\section{R E S U M O}

Objetivos: avaliar o panorama do câncer de pele em comunidades pomeranas do Estado do Espírito Santo, compostas por descendentes de imigrantes europeus, quanto ao sexo e idade ao diagnóstico, tamanho da lesão e tipo histológico. Método: foram avaliados laudos histopatológicos de 3781 pacientes operados entre os anos de 2000 e 2010, com ressecção de 4881 lesões. Foram avaliados tipo histológico, tamanho das lesões, idade e sexo dos pacientes ao diagnóstico e suas correlações no período de 11 anos. Resultados: 0 exame histopatológico evidenciou carcinoma basocelular em 3159 pacientes (83,5\%), carcinoma espinocelular em 415 (11\%), melanoma em $64(1,7 \%)$ e 143 pacientes (3,8\%) apresentaram lesões combinadas de carcinoma basocelular e carcinoma espinocelular. Quanto ao tamanho, 47,1\% media entre 5,1 e $10 \mathrm{~mm}$. O grupo etário de 61 aos 70 anos foi o que sofreu o maior número de intervenções cirúrgicas $(24,3 \%)$. Houve predomínio do sexo feminino $(53,6 \%, n=2027)$ em relação ao masculino $(46,4 \%, n=1754)$. Conclusão: o carcinoma basocelular foi o tipo histológico mais frequente. As prevalências do carcinoma espinocelular e do melanoma se situaram abaixo da estimativa nacional do Instituto Nacional de Câncer. O diagnóstico dos tumores ocorreu em idades mais avançadas (acima de 60 anos) e houve aumento da incidência e dimensões dos tumores de pele na população masculina.

Descritores: Neoplasias Cutâneas. Carcinoma Basocelular. Carcinoma de Células Escamosas. Exposição Ocupacional. Emigrantes e Imigrantes.

\section{REFERENCES}

1. Brasil. Ministério da Saúde. Instituto Nacional de Câncer José de Alencar Gomes da Silva. Estimativa 2012: incidência de câncer no Brasil. Rio de Janeiro: Inca; 2011.

2. Ferreira FR, Nascimento LFC. Câncer cutâneo em Taubaté (SP) - Brasil, de 2001 a 2005: um estudo de prevalência. An Bras Dermatol. 2008;83(4):317-22.

3. Castro LGM, Freire MA, Toyama CL, Britto TL, Gomes AP. Câncer de pele em clínica particular em São Paulo-SP. An Bras Dermatol. 1996;71(6):471-6.

4. Bechelli LM, Curban GV. Compêndio de dermatologia. São Paulo:Atheneu; 1978.

5. Zalaudek I, Whiteman D, Rosendahl C, Menzies SW, Green AC, Hersey P, et al. Update on melanoma and non-melanoma skin cancer. Annual Skin Cancer Conference 2011, Hamilton Island, Australia, 5-6 August 2011. Expert Rev Anticancer Ther. 2011;11(2):1829-32.

6. Zalaudek I, Giacomel J, Schmid K, Bondino S, Rosendahl C, Cavicchini S, et al. Dermatoscopy of facial actinic keratosis, intraepidermal carcinoma, and invasive squamous cell carcinoma: a progression model. J Am Acad Dermatol. 2011;66(4):589-97.

7. Naldi L, DiLandro A, D'Avanzo B, Parazzini F. Host-related and environmental risk factors for cutaneous basal cell carcinoma: evidence from an Italian case-control study. J Am Acad Dermatol. 2000;42(3):446-52.
8. Maafs E, De la Barreda F, Delgado R, Mohar A, Alfeirán A. Basal cell carcinoma of trunk and extremities. Int J Dermatol. 1997;36(8):622-8.

9. Machado Filho CAS, Fagundes DS, Sender F, Saraiva GL, Paschoal LHC, Costa MCC, et al. Neoplasias malignas cutâneas: estudo epidemiologico. An Bras Dermatol. 1996;71(6):479-84.

10. Bariani RL, Nahas FX, Barbosa MV, Farah AB, Ferreira LM. Carcinoma basocelular: perfil epidemiológico e terapêutico de uma população urbana. Acta Cir Bras. 2006;21(2):66-73.

11. Nasser N. Epidemiologia dos cânceres espinocelulares. Blumenau (SC) - Brasil, de 1980-1999. An Bras Dermatol. 2004;79(6):669-77.

12. Nasser N. Epidemiologia dos carcinomas basocelulares em Blumenau, SC, Brasil, de 1980-1999. An Bras Dermatol. 2005;80(4):363-8.

13. Silveira ML, Casalechi HL, Casalechi VL, Novo NF, Barbo MLP, Ruiz LRB. Estudo epidemiológico dos carcinomas basocelulares, na população atendida no Conjunto Hospitalar de Sorocaba, no período de 2001 a 2005. In: XI Encontro Latino-Americano de Iniciação Científica e VII Encontro Latino-Americano de Pós-Graduação; 2007; São José dos Campos(SP): Universidade do Vale do Paraíba, 2007.

14. Kumar P, Orton Cl, McWilliam LJ, Watson S. Incidence of incomplete excision in surgically treated basal cell carcinoma: a retrospective clinical audit. Br J Plast Surg. 2000;53(7):563-6.

15. Mureau MA, Moolenburgh SE, Levendag PC, Hofer SO. Aesthetic and functional outcome fol- 
lowing nasal reconstruction. Plast Reconstr Surg. 2007;120(5):1217-27.

16. Telfer NR, Colver GB, Morton CA; British Association of Dermatologists. Guidelines for the management of basal cell carcinoma. $\mathrm{Br} J$ Dermatol. 2008;159(1):35-48.
Received in: 12/09/2016

Accepted for publication: 01/12/2016

Conflict of interest: none.

Source of funding: none.

Mailing address:

Patricia Henriques Lyra Frasson

E-mail: patricialyra@uol.com.br

patricialyra@gmail.com 